\title{
Indo-Pacific Warm Pool convection and ENSO since 1867 derived from Cambodian pine tree cellulose oxygen isotopes
}

\author{
Mengfan Zhu, ${ }^{1}$ Lowell Stott, ${ }^{1}$ Brendan Buckley, ${ }^{2}$ Kei Yoshimura, ${ }^{3}$ and Koy Ra ${ }^{4}$ \\ Received 20 November 2011; revised 30 April 2012; accepted 6 May 2012; published 12 June 2012.
}

[1] The Indo-Pacific Warm Pool (IPWP) is a major source of heat and moisture to the atmosphere and thus strongly influences the global climate. In this study, we investigate how moisture fluxes from the IPWP influence the stable isotope signature of precipitation over Southeast Asia by analyzing the oxygen isotopic composition $\left(\delta^{18} \mathrm{O}\right)$ of tree cellulose from southern Cambodia. The cellulose $\delta^{18} \mathrm{O}$ record, spanning AD 1867-2006, documents a regular seasonal cycle with an average amplitude of $\sim 4 \%$ that is primarily controlled by seasonal differences in the isotopic composition of precipitation. Using the outputs from an isotope-enabled atmospheric model, we illustrate how the $\delta^{18} \mathrm{O}$ of precipitation at our site is predominantly controlled by the amount of rainout that occurs over the moisture source region, the IPWP. This is verified by strong correlations of our cellulose $\delta^{18} \mathrm{O}$ record with instrumental measurements of precipitation and outgoing longwave radiation over the IPWP, suggesting that the cellulose $\delta^{18} \mathrm{O}$ could be used to reconstruct the convection intensity over the IPWP. Spectral analysis of the cellulose $\delta^{18} \mathrm{O}$ reveals significant peaks at 2-7 years corresponding to ENSO frequencies. The variability of the cellulose $\delta^{18} \mathrm{O}$ record on the ENSO band exhibits characteristics that match existing coral $\delta^{18} \mathrm{O}$ records from the tropical Pacific, with reduced amplitude of variability in the 1920s through the 1960s, a period of weak ENSO activity.

Citation: Zhu, M., L. Stott, B. Buckley, K. Yoshimura, and K. Ra (2012), Indo-Pacific Warm Pool convection and ENSO since 1867 derived from Cambodian pine tree cellulose oxygen isotopes, J. Geophys. Res., 117, D11307, doi:10.1029/2011JD017198.

\section{Introduction}

[2] The Indo-Pacific Warm Pool (IPWP) is a major heat and moisture source to the atmosphere's convective overturning in both the Hadley circulation and the Walker circulation. Variable heat exchange between the surface ocean and the atmosphere in the tropical Pacific on interannual time scales associated with El Niño-Southern Oscillation (ENSO) has a strong influence on climatic conditions globally [McPhaden and Picaut, 1990]. Climate modeling as well as paleoclimate studies also suggest that changing temperatures within the tropical warm pool may have been an important influence on climate changes from decadal to millennial time scales [Clement et al., 2001; Linsley and Thunell, 1990; Stott

\footnotetext{
${ }^{1}$ Department of Earth Sciences, University of Southern California, Los Angeles, California, USA.

${ }^{2}$ Tree Ring Lab, Lamont-Doherty Earth Observatory, Columbia University, Palisades, New York, USA.

${ }^{3}$ Atmospheric and Ocean Research Institute, University of Tokyo, Tokyo, Japan.

${ }^{4}$ Cambodia Development Resource Institute, Phnom Penh, Cambodia.

Corresponding author: M. Zhu, Department of Earth Sciences, University of Southern California, 3651 Trousdale Pkwy., Los Angeles, CA 90089, USA. (mengfanz@usc.edu)

C 2012. American Geophysical Union. All Rights Reserved.
}

et al., 2002; Timmermann et al., 1999]. In efforts to document how the tropical hydrological cycle changes with global warming, model simulations and reanalysis data for the 20th century provide somewhat contradictory results, with regard to whether it is strengthening [Mitas and Clement, 2005] or weakening [Tanaka et al., 2005]. Unfortunately, instrumental measurements for the tropical surface oceans are sparse prior to 1950, and satellite observations barely extend beyond the past three decades [Chen et al., 2002; Wielicki et al., 2002]. Longer, higher resolution records derived from proxies that can capture the hydrologic variability could extend the instrumental records and help resolve these discrepancies.

[3] Past studies utilizing marine sediment proxies (foraminiferal stable isotope and $\mathrm{Mg} / \mathrm{Ca}$ records) and speleothem isotope records have documented millennial to centennial scale changes in tropical temperatures and moisture fluxes that were coincident with high latitude climate variability, and this may be indicative of how the warm pool in the Pacific can modulate energy in the global climate system [Newton et al., 2006; Oppo et al., 2009; Partin et al., 2007; Stott et al., 2002; Visser et al., 2003]. Corals in the tropical oceans have provided high-resolution information about the sea surface conditions in the past few centuries, and this has improved our understanding of the ENSO-related variability [Asami et al., 2005; Charles et al., 1997, 2003; Cole et al., 1993, 2000; Quinn et al., 1996, 1998, 2006; Urban et al., 


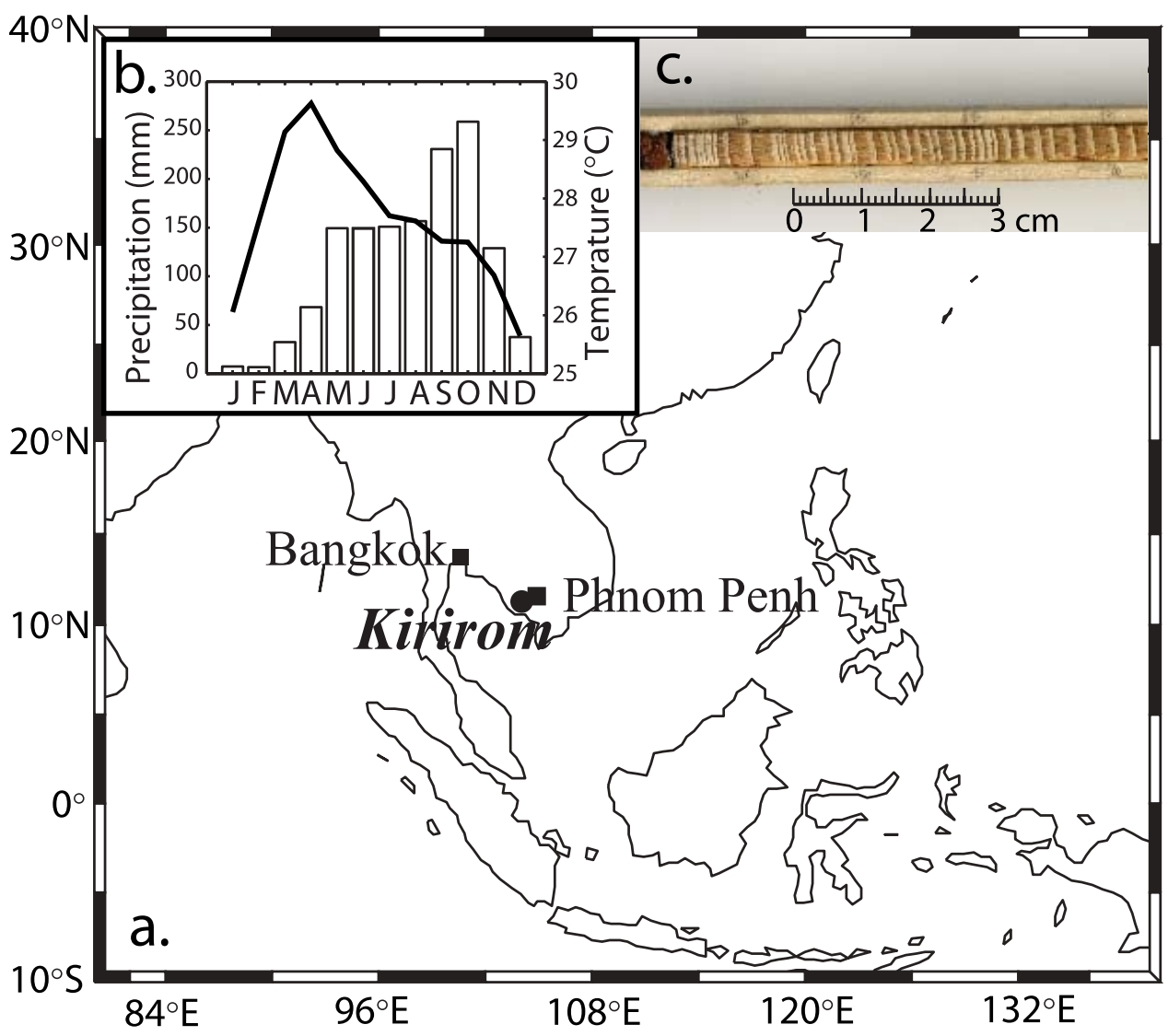

Figure 1. (a) Map of Southeast Asia showing the sampling site Kirirom, the nearby meteorological station Phnom Penh, and the GNIP station Bangkok. (b) Climatology at Phnom Penh, with temperature in line, and precipitation in bars. (c) Scanned image of a tree core sample showing the annual ring structures.

2000]. In an attempt to augment these oceanographic records with a terrestrial counterpart that has high temporal resolution, we investigate how the isotopic composition of tropical moisture is conveyed from the ocean to the land by analyzing the isotopic composition of cellulose extracted from the annual rings of tropical trees.

[4] In this study, we have analyzed the oxygen isotopic composition $\left(\delta^{18} \mathrm{O}\right)$ of tree cellulose for the past 140 years from trees growing in a tropical forest in Cambodia where the regional climate is sensitive to the oceanic and atmospheric behavior within IPWP [Buckley et al., 2010]. At this study location the tree cellulose records the $\delta^{18} \mathrm{O}$ of rainwater that is transferred to soil moisture. By sampling the annual tree rings at sub-annual resolution we reconstruct the $\delta^{18} \mathrm{O}$ of precipitation during different stages of the rainy season. We demonstrate that the precipitation $\delta^{18} \mathrm{O}$ at this location as inferred from the cellulose record is influenced by the strength of atmospheric convection over the IPWP as well as ENSO activities. We then compare our cellulose $\delta^{18} \mathrm{O}$ record to existing coral $\delta^{18} \mathrm{O}$ records in the tropical Pacific Ocean and discuss their similar variabilities.

\section{Materials and Methods}

[5] Our study site is Kirirom National Park (675 m, 11.29 ${ }^{\circ} \mathrm{N}, 104.25{ }^{\circ} \mathrm{E}$; Figure 1a) in southern Cambodia. At this location in Southeast Asia, there is strong seasonality in precipitation (Figure 1b). During the boreal winter from December to March there is very little or no precipitation. The months of May to October are the rainy season. The onset of the Indian summer monsoon typically occurs in May, with the development of the land-sea thermal contrast and a significant increase in both heat and moisture during the month of April. The strong southwesterly monsoon winds carry large amounts of moisture from the tropical Indian Ocean and the Bay of Bengal to the Mainland Southeast Asia. This southwesterly wind pattern generally lasts until mid-September, after which the Indian summer monsoon retreats. Mainland Southeast Asia is then dominated by easterly winds that transport moisture from the South China Sea and the Maritime Continent region (Figure 2), and this leads to the peak in precipitation between September and October (Figure 1b). The precipitation that falls over Kirirom during these two rainy periods has distinctly different isotopic compositions, which reflect their different moisture sources [Aggarwal et al., 2004].

[6] Kirirom is the southernmost location in mainland Southeast Asia where true pines are found. Sample cores of Merkus pine (Pinus merkusii Junghuhn \& De Vriese) were collected in 2009. Consistent with the rainfall pattern, Merkus pine grows rapidly during the wet season from May to October. The cambial activity declines gradually as the dry season starts in November, and becomes dormant until the end of the dry season March-April [Pumijumnong and Wanyaphet, 2006]. This growth pattern results in clear ring structures. Each annual ring begins with a light colored early wood that is characterized by large tracheid cells with thin walls and 

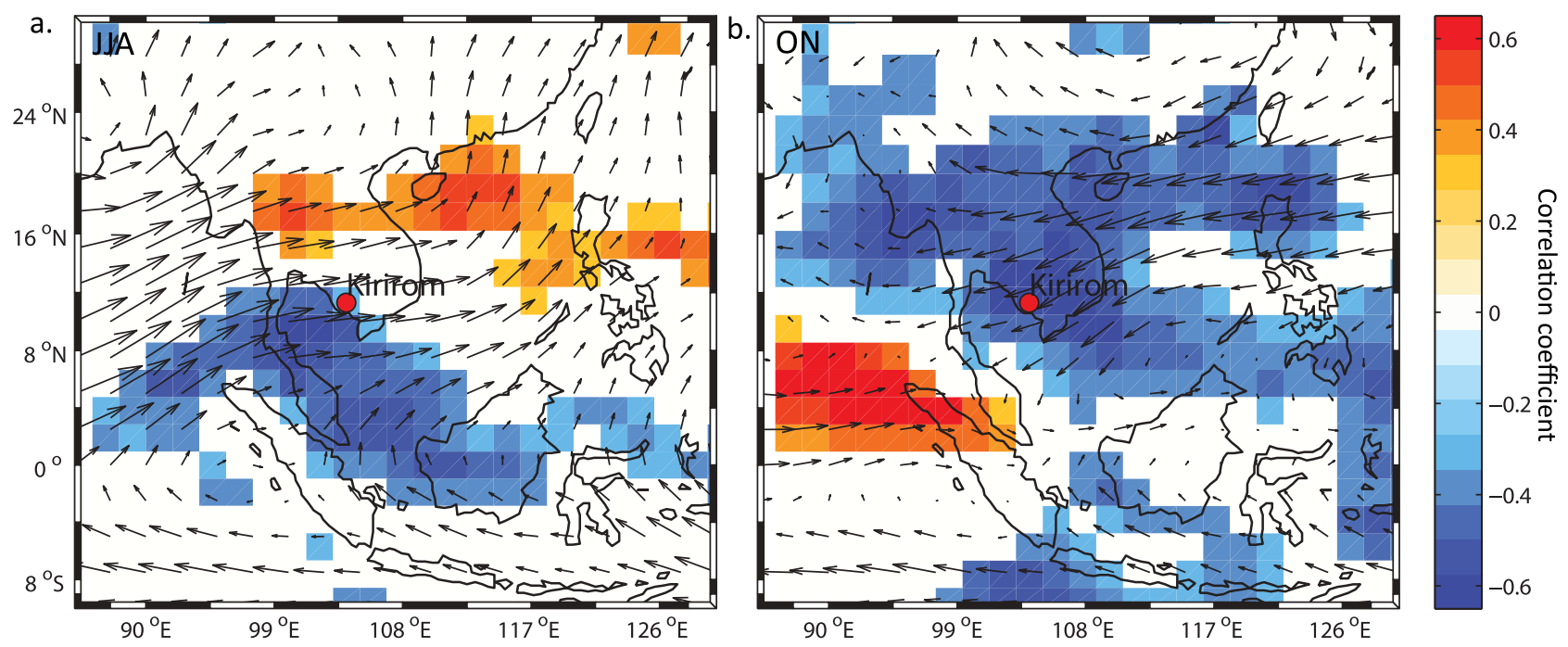

Figure 2. The long-term mean wind vectors at $850 \mathrm{mbar}$ level for the rainy months of (a) June-JulyAugust, which represents the Indian summer monsoon season, and (b) October-November, which represents the rainy period after the Indian summer monsoon retreats. Also shown in color for each rainy period is the spatial correlation between the precipitation $\delta^{18} \mathrm{O}$ at Kirirom and the field of precipitation amount. Only correlation above $90 \%$ significance level is shown. The data for wind vectors, precipitation $\delta^{18} \mathrm{O}$ and precipitation amount are all from IsoGSM model outputs.

large lumens, and lower in density than the thicker walled latewood cells with small lumens (Figure 1c). In some years, there are missing rings and false rings due to unusual growth. In spite of that, Merkus pine has been successfully cross-dated in Thailand and Laos [Buckley et al., 2007; D'Arrigo et al., 1997; Pumijumnong and Eckstein, 2011]. The cores used in this study were cross-dated in the Tree Ring Lab at LamontDoherty Earth Observatory. The Expressed Population Signal (EPS) value [Wigley et al., 1984] is above 0.85 back to 1850 , with an overall series inter-correlation of 0.503 and mean sensitivity of 0.287 for a selected subset of cores (Buckley et al., manuscript in preparation). For isotope analysis, we selected three cores based on the criteria of small numbers of missing or false rings and regular ring boundaries [Leavitt et al., 2010].

[7] The cores selected were drilled from three individual trees that were growing a few kilometers apart, thereafter identified as KRPM09A, KRPM10A and KRPM15B. Each core was sliced parallel to ring boundaries using a microtome. Subannual samples of each ring were obtained by carefully spacing discrete slices over the width of an annual ring. The wood samples were then processed using a modified Brendel method [Gaudinski et al., 2005] to extract $\alpha$-cellulose. The cellulose samples were analyzed for their oxygen isotopic ratio $\left(\delta^{18} \mathrm{O}\right)$ using a Thermo Finnigam TC/EA coupled with a Delta V Advantage IRMS. Results were reported in $\delta$ notation relative to vSMOW. The analytical precision, based on repeated measurements of interspaced cellulose standards (IAEA cellulose and baker cellulose), was $\pm 0.3 \%$.

[8] The sub-annual sampling strategy allows us to examine the $\delta^{18} \mathrm{O}$ of tree cellulose produced at monthly to weekly time resolution. The $\delta^{18} \mathrm{O}$ of cellulose is primarily a function of the $\delta^{18} \mathrm{O}$ of soil moisture, which a tree obtains through its root system, as well as the relative humidity of the ambient environment during growth, which controls the rate of evapotranspiration and its associated isotope fractionation [Sternberg, 2009]. The trees we sampled were growing at ridge lines where rainwater drains rapidly from the soil and thus there is minimal groundwater storage. This means the water used by the trees to synthesize cellulose is the water that falls more-or-less simultaneously with tree growth and cellulose production. During the rainy season, high relative humidity suppresses the evapotranspiration, so the $\delta^{18} \mathrm{O}$ of cellulose is mainly controlled by the $\delta^{18} \mathrm{O}$ of rainwater. In the tropics, the rainy season is characterized by isotopically depleted (more negative $\delta^{18} \mathrm{O}$ ) rainwater due to the so-called isotope amount effect [Araguás-Araguás et al., 1998]. In contrast to the rainy season, the dry season precipitation is more isotopically enriched (more positive $\delta^{18} \mathrm{O}$ ), and lower humidity enhances the evapotranspiration, which leads to a further enrichment in the $\delta^{18} \mathrm{O}$ of tree cellulose [Evans and Schrag, 2004]. By analyzing cellulose at subannual resolution, we capture these seasonal variations in $\delta^{18} \mathrm{O}$ and extract the climatological and ecological influences in different seasons.

\section{Results}

[9] We analyzed Core KRPM15B from 1867 to 2006. Cores KRPM10A and KRPM09A were analyzed discontinuously for several intervals to replicate the continuous record of KRPM15B, and also because the other intervals were broken in small pieces and were difficult to slice. All three cores correspond with one another very well in terms of both intra-annual and interannual variabilities (Figure 3). The most depleted $\delta^{18} \mathrm{O}$ value occurs at the center of each ring, where the ring grows fast during the rainy season, and the most enriched $\delta^{18} \mathrm{O}$ value occurs near the ring boundary, where the ring growth slows down or even stops during the dry season. 

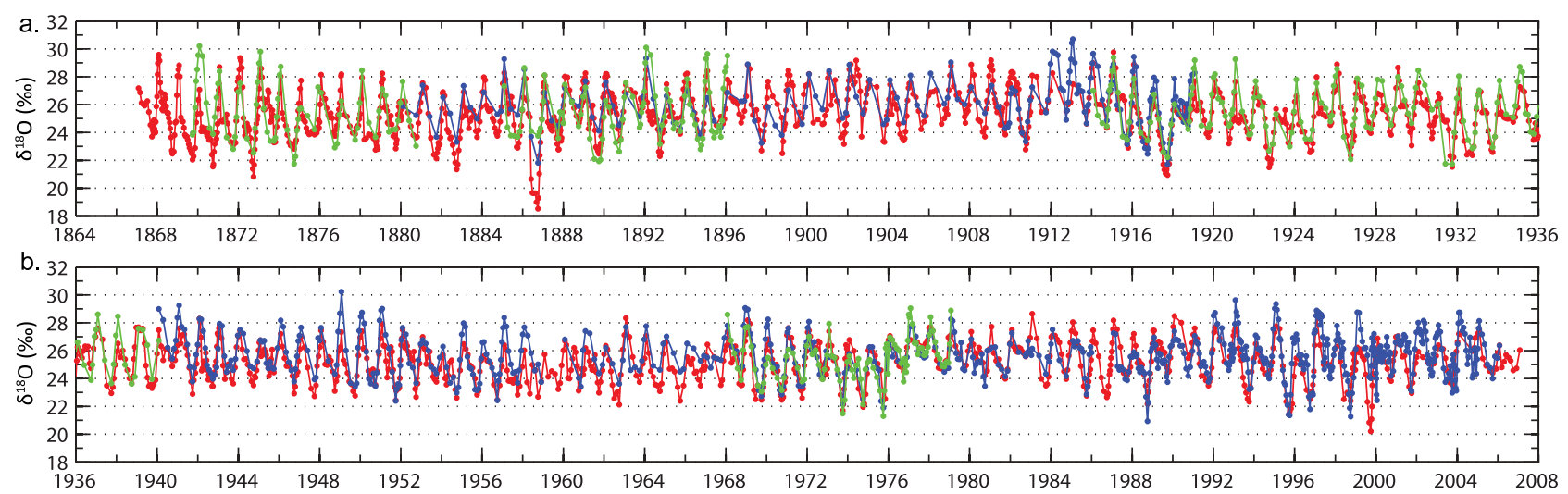

Figure 3. ( $\mathrm{a}$ and $\mathrm{b})$ Subannual cellulose $\delta^{18} \mathrm{O}$ measurements of the three cores KRPM15B (red), KRPM10A (blue) and KRPM09A (green).

[10] This intra-annual variation in cellulose $\delta^{18} \mathrm{O}$ is primarily reflective of the seasonal difference in precipitation $\delta^{18} \mathrm{O}$ as well as relative humidity. A composite of the intraring $\delta^{18} \mathrm{O}$ variation pattern from all individual rings reveals an annual cycle with mean amplitude of $\sim 4 \%$ (Figure 4a). We compare this with composites of the seasonal cycle of precipitation $\delta^{18} \mathrm{O}$ from two data sources. First, we select instrumental measurements of rainwater $\delta^{18} \mathrm{O}$ from Bangkok as part of the Global Network of Isotopes in Precipitation (GNIP) data set. Bangkok is located about $450 \mathrm{~km}$ to the northwest of Kirirom (Figure 1a) and is the nearest GNIP station with a relatively long and complete record that dates back to 1968 . We also select precipitation $\delta^{18} \mathrm{O}$ simulated by an isotope-enabled atmospheric model IsoGSM [Yoshimura et al., 2008], which has published data from 1979 to 2008. For this comparison we utilize the model outputs of precipitation $\delta^{18} \mathrm{O}$ at the grid point nearest to Kirirom. Both GNIP and IsoGSM precipitation $\delta^{18} \mathrm{O}$ exhibits similar seasonal pattern (Figures $4 \mathrm{~b}$ and $4 \mathrm{c}$ ). During the dry season from November to April, the precipitation is isotopically enriched. This rainwater, together with a further isotopic enrichment associated with enhanced evapotranspiration leads to $\delta^{18} \mathrm{O}$ values of tree cellulose that are the most enriched in an annual ring. From May to early September, this region receives large amounts of rainfall from the Indian summer monsoon moisture, and the precipitation $\delta^{18} \mathrm{O}$ is depleted due to the amount effect of the monsoon rainfall. The precipitation is even more isotopically depleted in midSeptember through October, when Indian summer monsoon retreats and the moisture source is diverted to the South China Sea-Maritime Continent region (Figure 2). We therefore attribute the most isotopically depleted part of the tree ring, i.e., the cellulose $\delta^{18} \mathrm{O}$ annual minimum value, to the growth that uses the most isotopically depleted rainwater during October. The interannual variability of the Kirirom cellulose $\delta^{18} \mathrm{O}$ annual minima correlates significantly with the precipitation $\delta^{18} \mathrm{O}$ in October from both GNIP and IsoGSM data sets (Table 1).

[11] It is difficult to assess how much tree ring growth has occurred in the rainy season versus in the dry season. In
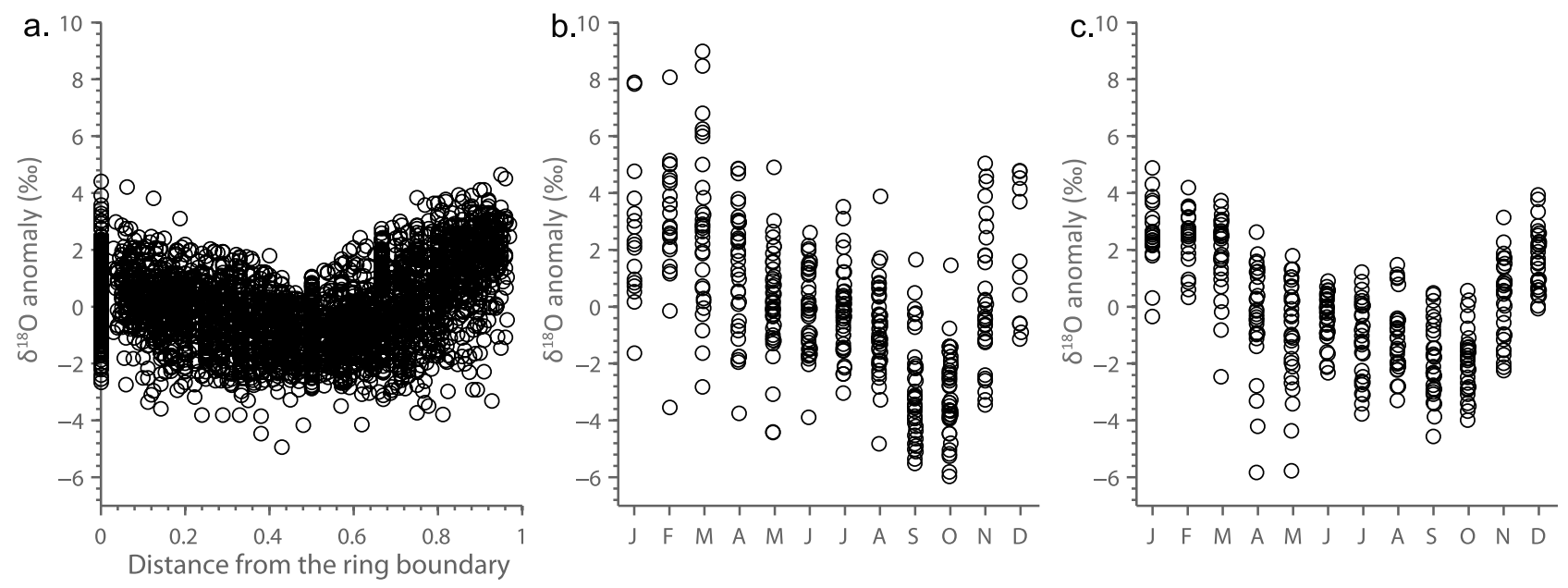

Figure 4. (a) Intra-annual variation of the cellulose $\delta^{18} \mathrm{O}$ composited from all the individual annual rings of all three cores. Horizontal axis represents the distance to the ring boundary with respect to the width of the ring. Anomalies are taken by subtracting annual means from the raw $\delta^{18} \mathrm{O}$ values to get rid of the interannual variation. (b) Same but for precipitation $\delta^{18} \mathrm{O}$ from GNIP observations in Bangkok. (c) Same but for precipitation $\delta^{18} \mathrm{O}$ from monthly IsoGSM outputs. 
Table 1. Correlation Coefficients Between the Cellulose $\delta^{18} \mathrm{O}$ Annual Minimum Values (KRPM09A, KRPM10A, KRPM15B and KRPM Average) and the Precipitation $\delta^{18} \mathrm{O}$ Values in October (IsoGSM Kirirom and GNIP Bangkok) $^{\mathrm{a}}$

\begin{tabular}{lcccc}
\hline & KRPM09A $^{\mathrm{b}}$ & KRPM10A & KRPM15B & $\begin{array}{c}\text { KRPM } \\
\text { Average }\end{array}$ \\
\hline IsoGSM Kirirom & - & 0.60 & 0.49 & 0.60 \\
GNIP Bangkok & - & 0.53 & 0.64 & 0.63 \\
\hline
\end{tabular}

\footnotetext{
${ }^{a}$ All correlation coefficients are above $99 \%$ significance level.

${ }^{b}$ For KRPM09A, there are not enough overlapping data with the precipitation $\delta^{18} \mathrm{O}$
}

order to generate continuous time series, we develop a simplified age model for the cellulose $\delta^{18} \mathrm{O}$ by assigning October to the cellulose $\delta^{18} \mathrm{O}$ annual minima and February to the cellulose $\delta^{18} \mathrm{O}$ annual maxima. From these tie points, adjacent samples are linearly interpolated to monthly resolution. The monthly interpolated series for all three cores are correlated to assess the reproducibility. Correlation coefficients are calculated for monthly interpolated $\delta^{18} \mathrm{O}$ values, monthly anomalies after subtracting the long-term mean for each month, annual minimum (October) values, and annual mean values. We also calculated the EPS values to evaluate the strength of the common signals. The correlation coefficients and EPS values are listed in Table 2. They are strong and significant, thus indicating good reproducibility among the three cores.

[12] The monthly interpolated cellulose $\delta^{18} \mathrm{O}$ from all three cores are then averaged to produce a single time series (Figure 5a). No conspicuous long-term trend is detected in the cellulose $\delta^{18} \mathrm{O}$. However, there is an interannual variability that appears to be ENSO-related. For example, in El Niño years of 1891, 1925, 1972, 1977, 1982, 1994, 1997 and 2002 [Gergis and Fowler, 2009], the cellulose record exhibits smaller annual cycles. In particular, the $\delta^{18} \mathrm{O}$ annual minima in these years are more enriched compared to adjacent years. Conversely, La Niña years of 1886, 1917, 1922, 1973, 1988, 1995, and 1998 [Gergis and Fowler, 2009] are marked by cellulose $\delta^{18} \mathrm{O}$ annual minima that are more depleted. In addition to these interannual differences, there are also notable decadal changes such as the 1976-1977 shift toward more enriched $\delta^{18} \mathrm{O}$ values, which coincides with the climate regime shift in the Pacific Ocean [Deser et al., 2004; Mantua and Hare, 2002].

[13] The cellulose $\delta^{18} \mathrm{O}$ annual maximum values, which we interpret as reflecting values associated with growth conditions during February, do not have significant correlation with any climate data, possibly due to complication of leaf evaporative enrichment during the dry season [Roden et al., 2000]. Moreover, it is likely that the trees become dormant or grow extremely slowly during the dry months, in which case, the interpolated $\delta^{18} \mathrm{O}$ values for the winter dry months in our record may not accurately represent these months.

[14] The more depleted cellulose $\delta^{18} \mathrm{O}$ values associated with the wet summer months are governed by a simpler mechanism that primarily involves the $\delta^{18} \mathrm{O}$ of precipitation and the associated isotope amount effect. This is because the trees grow faster during the rainy months, developing majority of the material in the annual rings, and high humidity reduces the influence of fractionation associated with evapotranspiration. Hence the most isotopically depleted portion of the annual ring, as resulted from our high resolution sampling, more reliably reflects the true growth during the rainy months and is more easily interpreted as climate signals. Indeed, warm and cold ENSO events are associated with less and more depleted cellulose $\delta^{18} \mathrm{O}$ annual minima, respectively, as illustrated previously. For this reason, we take out only the cellulose $\delta^{18} \mathrm{O}$ annual minima, which are interpreted to reflect rainfall in October, and calculate the anomalies with respect to the long-term mean through 1867-2006 (Figure 5b). Most recent El Niño events appear as positive anomalies, and $\mathrm{La}$ Niña years as negative anomalies. In the following, we discuss how ENSO is recorded in our cellulose record through convection over the IPWP region, using model outputs from IsoGSM as well as observations from both our cellulose $\delta^{18} \mathrm{O}$ record and instrumental climate data sets.

\section{Discussion}

\subsection{Convective Activity Over the Warm Pool}

[15] With its warmest surface water, the IPWP supplies large amounts of heat and moisture to the atmosphere through its intense convection. During the processes of condensation and precipitation, water isotopes fractionate. Heavier isotopes $\left(\mathrm{D},{ }^{18} \mathrm{O}\right)$ preferentially rain out and leave the remaining atmospheric moisture more isotopically depleted. Therefore, stronger convective activity, i.e., more cloud formation and heavier precipitation, would result in more isotopically depleted atmospheric moisture. The convection intensity over the IPWP is further influenced by the oscillation of the atmospheric Walker Circulation that is related to ENSO variability. During normal or La Niña conditions, the ascending limb of the Walker Circulation is located over the IPWP. The intensive cloud formation and heavy rainout result in isotopically depleted atmospheric moisture over the IPWP. During El Niño, however, the strongest convection shifts eastward along with the eastward flow of the warm surface water. This suppresses convection and precipitation over the IPWP. Atmospheric water vapor over the IPWP thus remains isotopically enriched.

[16] Atmospheric moisture evaporated from the IPWP is responsible for wet season precipitation at our site of Kirirom in the coastal region of Cambodia. During the Indian summer monsoon months from May to mid-September, westerly winds transport moisture from the eastern tropical Indian Ocean and the Bay of Bengal, the western component of the IPWP (Figure 2a). During the later rainy period from midSeptember to October-November, winds over Cambodia shift to easterlies, drawing moisture from the South China Sea-Maritime Continent region, which is the eastern side of the IPWP (Figure 2b). The precipitation that falls at Kirirom

Table 2. Correlation Coefficients Between the Cellulose $\delta^{18} \mathrm{O}$ Values of Any Two Cores and the EPS Values ${ }^{\mathrm{a}}$

\begin{tabular}{lcccc}
\hline & $\begin{array}{c}\text { Monthly } \\
\text { Values }\end{array}$ & $\begin{array}{c}\text { Monthly } \\
\text { Anomalies }\end{array}$ & $\begin{array}{c}\text { Annual } \\
\text { Minima }\end{array}$ & $\begin{array}{c}\text { Annual } \\
\text { Mean }\end{array}$ \\
\hline KRPM09A versus 10A & 0.76 & 0.42 & 0.64 & 0.53 \\
KRPM09A versus 15B & 0.73 & 0.36 & 0.67 & 0.59 \\
KRPM10A versus 15B & 0.75 & 0.46 & 0.57 & 0.49 \\
EPS & 0.90 & 0.68 & 0.84 & 0.78 \\
\hline
\end{tabular}

${ }^{\mathrm{a}}$ All correlation coefficients are above $99 \%$ significance level. 

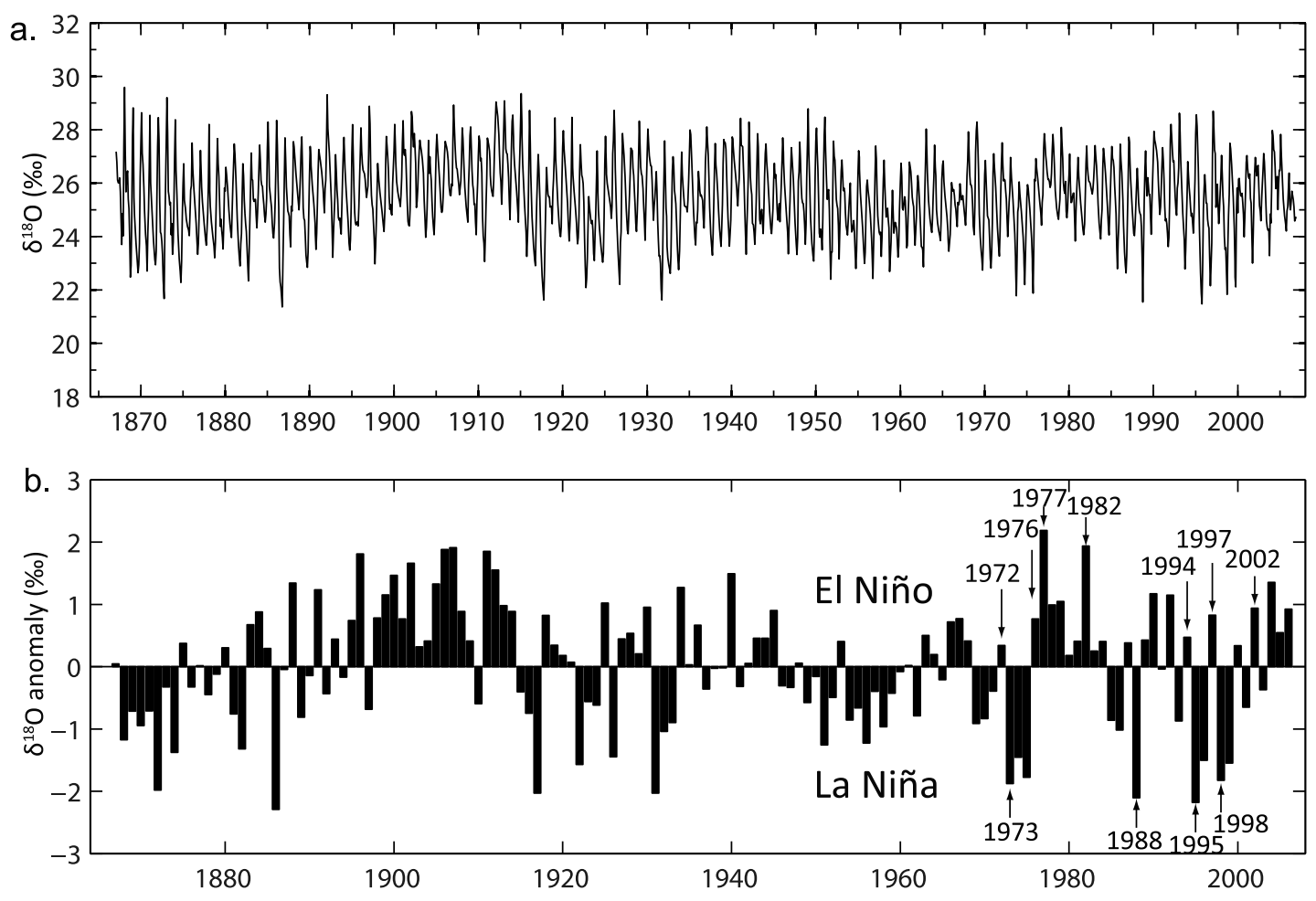

Figure 5. (a) Monthly interpolated cellulose $\delta^{18} \mathrm{O}$ averaged from three cores. (b) Anomalies of October cellulose $\delta^{18} \mathrm{O}$ after subtracting the long-term mean. Also shown are recent ENSO events.

therefore carries an isotopic signature that is similar to the IPWP atmospheric moisture, which is further determined by the intensity of convection and precipitation over the IPWP. We employ the model outputs of IsoGSM to test this idea. A spatial correlation between the time series of precipitation $\delta^{18} \mathrm{O}$ at Kirirom and the precipitation amount over the IPWP region is calculated for the two rainy periods as described above. These are plotted in Figure 2 along with the longterm mean wind vectors at the $850 \mathrm{mbar}$ level. For both rainy periods, the precipitation $\delta^{18} \mathrm{O}$ at Kirirom correlates negatively with the precipitation amount over most parts of the IPWP. In particular, the moisture source region that is upwind of air at the Kirirom site during each of the rainy periods determines the isotopic composition of rainwater at Kirirom. For example, during October-November, after the Indian summer monsoon retreats and when the easterlies dominate, the precipitation $\delta^{18} \mathrm{O}$ at Kirirom correlates best with the precipitation amount to its east and northeast, over the South China Sea-Maritime Continent region.

[17] In summary, the IsoGSM model outputs reinforce our assertion that the intensity of convection and the amount of rainout occurring over the IPWP region determines the isotopic composition of the rainwater at Kirirom, which is further transmitted to the cellulose of growing trees. On an interannual basis, convective uplift over the IPWP is influenced by ENSO variability. This explains why we observe a strong ENSO signal in our cellulose record (Figure 5b). On a seasonal basis, the moisture source region shifts in different months between different parts of the IPWP. Ideally, our monthly interpolated cellulose $\delta^{18} \mathrm{O}$ could track these seasonal shifts. In the following, we conduct further correlation analysis using the Kirirom cellulose record along with instrumental data sets to verify the above observations from the IsoGSM model outputs.

[18] We use CPC Merged Analysis of Precipitation (CMAP) and NOAA interpolated Outgoing Long-wave Radiation (OLR) as two instrumental proxies for convection over the IPWP [Johnson and Xie, 2010; Newman et al., 2000]. Both measure the convection intensity integrated through the atmospheric column, and are the longest available observational data sets of this kind that extend back to the 1970s. In these records stronger convective activity over the IPWP is expressed as heavier precipitation and less OLR (due to more clouds). However, our monthly interpolated cellulose $\delta^{18} \mathrm{O}$ does not correlate with CMAP or OLR in any other months other than October. We suspect our monthly interpolation strategy is flawed due to uncertainties in the growth behavior of the trees and associated artifacts that stem from our slicing subannual samples. It is therefore difficult to identify the individual cellulose values for each individual month based on a linear interpolation technique. Nevertheless, we believe the most depleted isotope values associated with October precipitation are well resolved in the cellulose $\delta^{18} \mathrm{O}$ annual minima.

[19] GNIP observations as well as IsoGSM model outputs have shown that October rainfall at our site in the southern part of Mainland Southeast Asia is distinctly depleted in heavier isotopes compared to the earlier Indian summer monsoon rainy season from May to mid-September, due to their different moisture sources. The magnitude of this isotopic difference is $\sim 4 \%$ o and remains stable on interannual basis (Figure 6). Other studies such as the work carried out by Aggarwal et al. [2004] have also noted that the moisture source of the western Pacific Ocean-Maritime Continent 

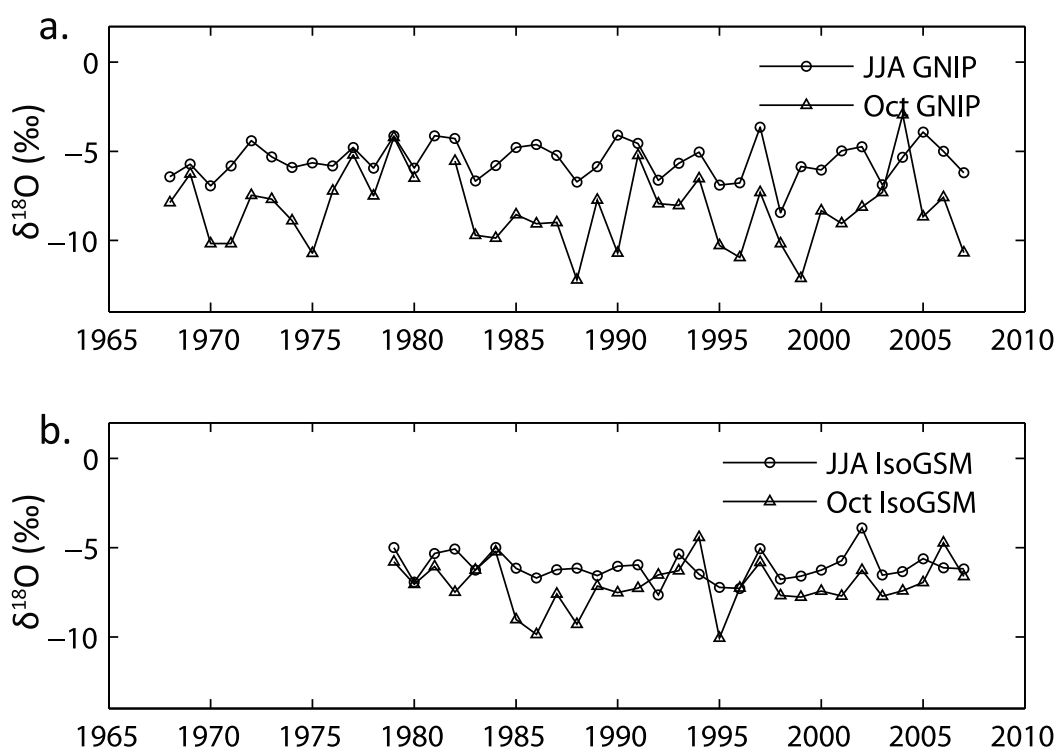

Figure 6. The difference in precipitation $\delta^{18} \mathrm{O}$ between June-July-August mean, when the moisture source is the Indian summer monsoon, and October, when the moisture source is the South China SeaMaritime Continent. Data are from (a) Bangkok GNIP record and (b) IsoGSM simulation at the grid point near Kirirom.

region is more isotopically depleted compared to the eastern tropical Indian Ocean-Bay of Bengal. Therefore, we believe the Kirirom cellulose $\delta^{18} \mathrm{O}$ annual minima are a robust representation of the rainfall $\delta^{18} \mathrm{O}$ that falls around October, when moisture is from the western Pacific Ocean-Maritime Continent region. The cellulose $\delta^{18} \mathrm{O}$ annual minima correlate strongly with both CMAP (negatively) and ORL (positively) over the western Pacific-Maritime Continent region in October to December (Figure 7). This is in agreement with the relationship indicated by the IsoGSM model outputs, suggesting that the cellulose $\delta^{18} \mathrm{O}$ has reasonably well preserved the information about the convection intensity over the IPWP.

[20] The correlation is also strong, but with opposite sign between cellulose $\delta^{18} \mathrm{O}$ at Kirirom and precipitation over the central equatorial Pacific, the Niño-4 region (Figure 7a), suggesting an influence of ENSO on the IPWP convection. The Niño-4 SST index for October correlates positively with Kirirom cellulose $\delta^{18} \mathrm{O}$ in October $(\mathrm{R}=0.56$, Figure 8$)$. Tenyear low-pass filters of these time series reveal that they also exhibit similar patterns of low-frequency variability, particularly after the 1920s. The decreased similarity prior to 1920 may be attributed to the decreased accuracy of observed SSTs in the earlier part of the record as they were interpolated from rather sparse observations [Kaplan et al., 1998]. Another possible explanation lies in the uncertainty in the ENSO mechanism and variability. We interpret the Kirirom cellulose record as a proxy for precipitation over the IPWP, whereas Niño-4 is an index for ENSO and SST in the central equatorial Pacific. The atmospheric connection that links the hydrology of IPWP to ENSO might have changed in the past. Moreover, whether ENSO expresses itself more in the central Pacific or eastern Pacific is under debate [Ashok et al., 2007; Kao and $Y u, 2009]$. Further investigation of this question necessitates a network of robust reconstructions.

\subsection{Comparison With Tropical Corals}

[21] Corals in the surface water of tropical oceans, particularly in the western and central tropical Pacific, have been used extensively to reconstruct sea surface conditions and ENSO activities. The $\delta^{18} \mathrm{O}$ of coral skeletons varies as a function of both SST and the $\delta^{18} \mathrm{O}$ of ambient seawater, the latter of which is related to precipitation [Cobb et al., 2003; Quinn et al., 2006]. During El Niño, the center of anomalously warm SSTs and high precipitation migrates toward the central equatorial Pacific. This leads to an isotopic depletion in the central Pacific corals. La Niña corresponds to cool and dry conditions and thus more enriched coral $\delta^{18} \mathrm{O}$ values in the central Pacific. Conversely, corals in the western Pacific warm pool region are isotopically enriched during El Niño and are more depleted during La Niña. We took advantage of existing coral $\delta^{18} \mathrm{O}$ records from both the central and western tropical Pacific regions to compare with the Kirirom cellulose $\delta^{18} \mathrm{O}$ record.

[22] Fourteen coral $\delta^{18} \mathrm{O}$ records are found within the IPWP and the central Pacific regions (Table 3 and Figure 7b), most of which were sampled and analyzed at monthly resolution. For consistency, we have also interpolated coral records with lower resolution to monthly resolution. From each record we derive an estimate of October-NovemberDecember (OND) mean coral $\delta^{18} \mathrm{O}$ (except for Vanuatu coral $\delta^{18} \mathrm{O}$, which is in annual resolution, and the annual $\delta^{18} \mathrm{O}$ is used instead), and correlate that to Kirirom October cellulose $\delta^{18} \mathrm{O}$. Eight coral records exhibit significant correlation with the Kirirom cellulose record (Table 3 ). The central Pacific corals (No. 4, 5, 6 and 14 on Figure 7b and Table 3) correlate negatively with Kirirom cellulose $\delta^{18} \mathrm{O}$, whereas western and southwestern Pacific corals (No. 2, 8, 11 and 12) correlate positively with the cellulose. These correlations reflect locations where corals record different relationships to hydrological conditions over the IPWP. Corals that are located in 

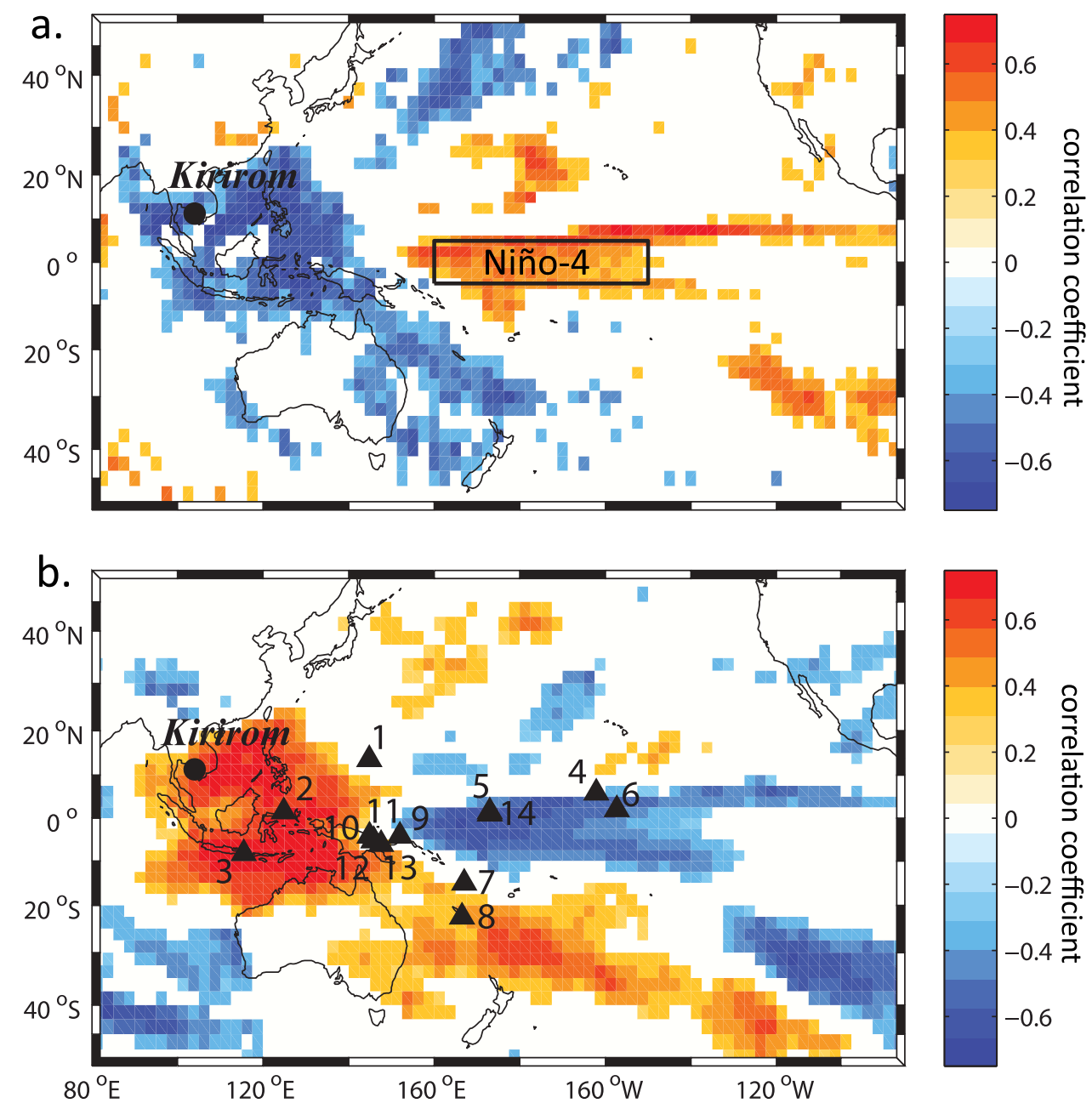

Figure 7. Spatial correlation of October Kirirom cellulose $\delta^{18} \mathrm{O}$ values with the October-NovemberDecember mean of (a) CMAP precipitation, and (b) NOAA interpolated OLR. Only correlation above $90 \%$ significance level is shown. Box in Figure 7a shows the Niño-4 region and triangles in Figure $7 \mathrm{~b}$ show the sites of tropical Pacific coral $\delta^{18} \mathrm{O}$ records (see Table 3 for details).

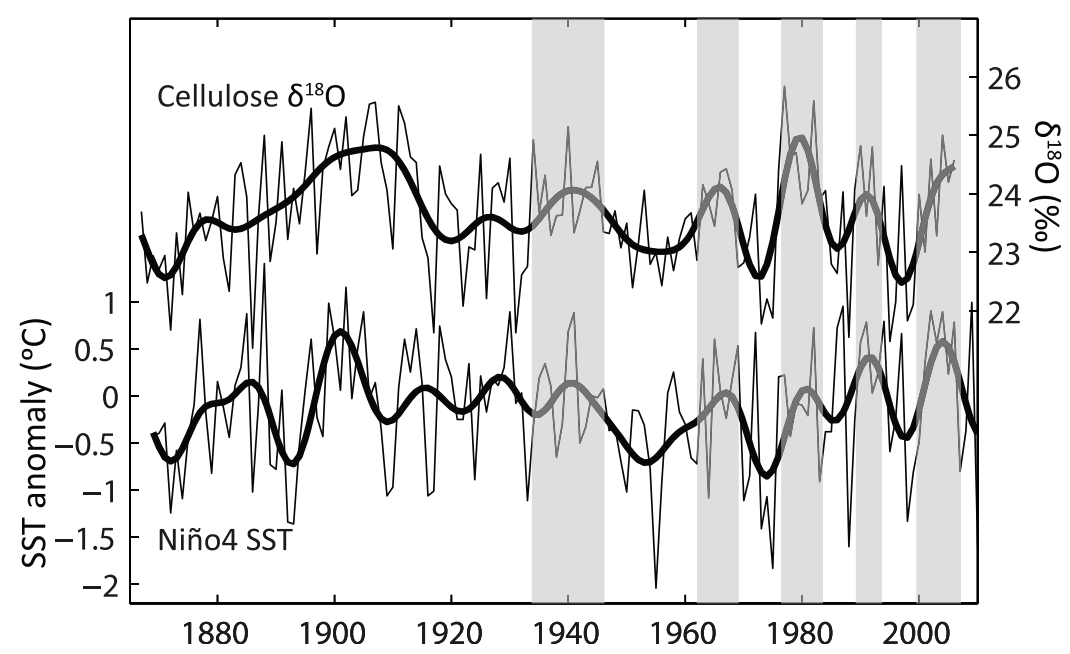

Figure 8. Correlation between Kirirom cellulose $\delta^{18} \mathrm{O}$ October values and Niño-4 SST index for October $(\mathrm{R}=0.56)$. Thick lines are the 10 -year low-pass filters. Shaded bars highlight the similar decadal variations between the two time series. 
Table 3. List of Coral $\delta^{18} \mathrm{O}$ Records in the Tropical Pacific Ocean, and the Correlation Coefficients (R) of Their October to December Mean With Kirirom Cellulose October ${ }^{\mathrm{a}}$

\begin{tabular}{|c|c|c|c|c|c|c|}
\hline Number ${ }^{b}$ & Latitude & Longitude & Site & Age & $\mathrm{R}$ & Reference \\
\hline 1 & 13.60 & 144.84 & Guam & $1790-2000$ & 0.13 & Asami et al. [2005] \\
\hline 2 & 1.50 & 124.83 & Bunaken & 1860-1990 & 0.40 & Charles et al. [2003] \\
\hline 3 & -8.25 & 115.50 & Bali & $1782-1990$ & 0.09 & Charles et al. [2003] \\
\hline 4 & 5.87 & -162.13 & Palmyra & 1886-1998 & -0.22 & Cobb et al. [2003] \\
\hline 5 & 1.50 & 173.00 & Tarawa & 1894-1990 & -0.38 & Cole et al. [1993] \\
\hline 6 & 2.00 & $-\mathbf{1 5 7 . 3 0}$ & Kiritimati & 1938-1993 & -0.44 & Evans et al. [1999] \\
\hline 7 & -15.00 & 167.00 & Vanuatu & $1806-1979$ & 0.12 & Quinn et al. [1996] \\
\hline 8 & -22.48 & 166.47 & Amedee & $1657-1992$ & 0.16 & Quinn et al. [1998] \\
\hline 9 & -4.18 & 151.98 & Rabaul & $1867-1997$ & 0.03 & Quinn et al. [2006] \\
\hline 10 & -5.22 & 145.82 & Madang95 & $1922-1991$ & 0.12 & Tudhope et al. [1995] \\
\hline 11 & -5.22 & 145.82 & Madang01 & $1880-1993$ & 0.27 & Tudhope et al. [2001] \\
\hline 12 & -4.15 & 144.88 & Laing & 1884-1993 & 0.29 & Tudhope et al. [2001] \\
\hline 13 & -6.08 & 147.60 & Huon & $1977-1995$ & 0.33 & Tudhope et al. [2001] \\
\hline 14 & 1.00 & 173.00 & Maiana & 1840-1994 & $-\mathbf{0 . 3 7}$ & Urban et al. $[2000]$ \\
\hline
\end{tabular}

${ }^{a}$ In bold are the eight corals records that correlate significantly with Kirirom cellulose record.

${ }^{\mathrm{b}}$ Correspond to numbers in Figure $7 \mathrm{~b}$.

the transitional region on the correlation map (No. 1, 7, 9, 10 and 13) do not show significant correlation with the cellulose record, as expected. Surprisingly, the Bali coral $\delta^{18} \mathrm{O}$ record (No. 3), which is situated right in the center of the IPWP where both CMAP and OLR strongly correlate with the Kirirom cellulose $\delta^{18} \mathrm{O}$ (Figure $7 \mathrm{~b}$ ), does not show good correlation.

[23] Most of the central Pacific coral $\delta^{18} \mathrm{O}$ records indicate a decreasing trend over the second half of the 20th century, which has been argued to be a possible manifestation of the 20th century SST warming [Cobb et al., 2003; Quinn et al., 1998]. However, this is no such trend in the Kirirom cellulose record (Figure 5). We attribute this to the fact that Kirirom cellulose $\delta^{18} \mathrm{O}$ mirrors precipitation variability over the IPWP. The small magnitude of the warming would have a minor influence on convective intensity because the SST threshold for tropical convection might co-vary with SSTs [Johnson and Xie, 2010]. Western Pacific corals generally have weaker correlation than central Pacific corals with the Kirirom record. This is likely due to the fact that coral $\delta^{18} \mathrm{O}$ contains both precipitation and temperature influences. In the central Pacific, both precipitation and SST co-vary with ENSO, which affects the hydrological conditions over the western Pacific.

[24] Most of the coral records exhibit strong variance at ENSO frequencies as reported by the authors. We applied a power spectral analysis to the Kirirom cellulose $\delta^{18} \mathrm{O}$ record to assess its major periodicities. Monthly interpolated cellulose $\delta^{18} \mathrm{O}$ was used instead of the October values in order to ensure a sufficiently high resolution to capture the ENSO $2-7$ year recurrence. Similar to the corals, the cellulose $\delta^{18} \mathrm{O}$ exhibits prominent variance on the 2-7 year band (Figure 9). We select five coral records that correlate best with our cellulose record and also have significantly long time spans (Tarawa, Maiana, and Palmyra from the central Pacific; Bunaken and Madang from the western Pacific). We then filter the monthly cellulose $\delta^{18} \mathrm{O}$ as well as the five monthly coral $\delta^{18} \mathrm{O}$ records using a 2-7 year window to examine their variability associated with ENSO (Figure 10). The band-pass filter of the cellulose $\delta^{18} \mathrm{O}$ varies in anti-phase with the three central Pacific coral $\delta^{18} \mathrm{O}$ and in phase with the two western Pacific coral $\delta^{18} \mathrm{O}$ records. Another common feature observed from the band-pass filters of all the six records is a reduced amplitude of variability between the 1920s and the 1960s, which is a well-recognized period with weak ENSO variability [Quinn et al., 2006].

[25] In addition to the interannual variability, there is also indication of a decadal mode at $\sim 13.5$ year cycle revealed by the power spectral analysis (Figure 9). Similar decadal variability has been documented in coral records ranging from the Pacific Ocean [Asami et al., 2005; Quinn et al., 1996, 1998] to the Indian Ocean [Charles et al., 1997, 2003]. Latif and Barnett [1994] suggested this decadal pattern might be related to an internal climate oscillation within the Pacific basin such as the Pacific Decadal Oscillation (PDO). For instance, the 1976-77 shift seen in our cellulose record as well as in many coral records is a transition in the PDO. By comparing the 6 years after the 1976-77 transition to the 6 years before the transition, Graham [1995] showed from both observations and a model simulation that the transition lead to a drier condition in the maritime continent and wetter conditions in the central equatorial Pacific. This is in agreement with our cellulose record, which suggests an isotopic enrichment after the transition. However, the

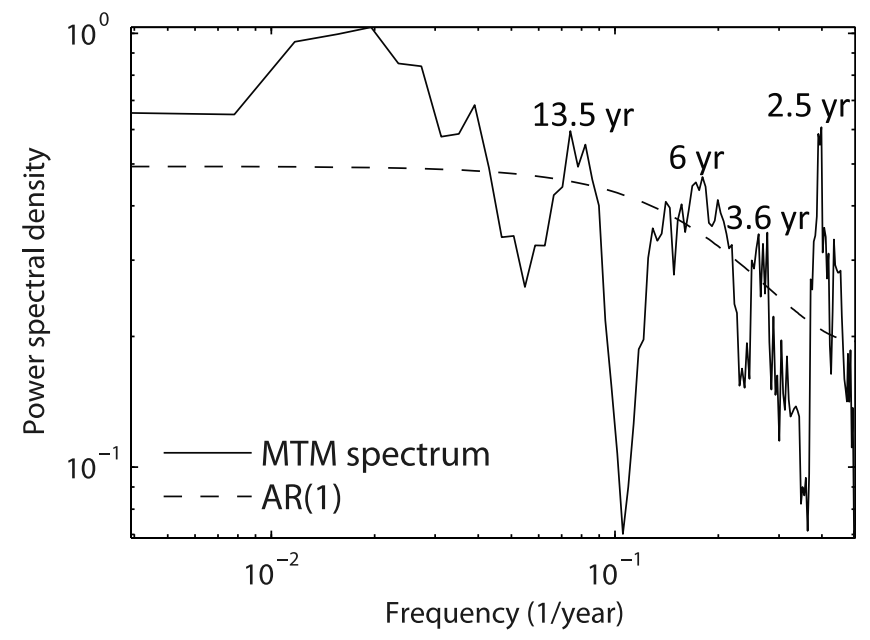

Figure 9. Power spectral density of the monthly Kirirom cellulose $\delta^{18} \mathrm{O}$ showing major periodicities at $2.5,3.6,6$, and 13.5 years. 


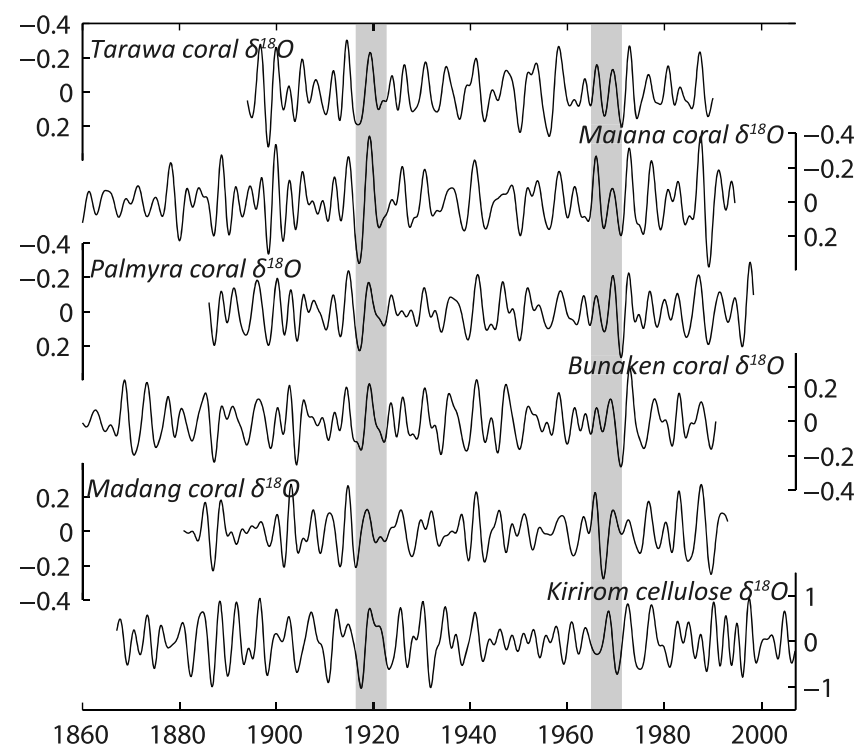

Figure 10. The 2-7 year band-pass filters of the five coral $\delta^{18} \mathrm{O}$ records and the Kirirom cellulose $\delta^{18} \mathrm{O}$ record. The central Pacific coral records (Tarawa, Maiana, and Palmyra) correlate negatively with the Kirirom cellulose $\delta^{18} \mathrm{O}$, therefore their $y$-axes are reversed. The western Pacific coral records (Bunaken and Madang) correlate positively with the cellulose record. Decreased variability between 1920 s and 1960s (interval between the shaded bars) appears to be the common feature of all the records.

mechanism behind this decadal variability as commonly seen in the tropical oceans still requires further investigation.

\section{Conclusions and Implications}

[26] In this study, we have analyzed the $\delta^{18} \mathrm{O}$ of tree cellulose for an evergreen species Pinus merkusii from a tropical forest in Cambodia in subannual resolution for the period AD 1867-2006. The cellulose $\delta^{18} \mathrm{O}$ exhibits regular seasonal cycle which is primarily attributed to the seasonal difference in the $\delta^{18} \mathrm{O}$ of precipitation. At this location in Southeast Asia, precipitation is influenced by two moisture sources, an early rainy period co-occurring with the Indian summer monsoon, and a late rainy period brought by easterlies from the South China Sea and the Maritime Continent. We are able to identify in the cellulose record the $\delta^{18} \mathrm{O}$ associated with the latter rainy period because of its distinctly depleted isotopic signature. This $\delta^{18} \mathrm{O}$ signal is further used to infer past changes in the hydrological cycle based on understandings of the "amount effect," an inverse relationship between the $\delta^{18} \mathrm{O}$ and the amount of precipitation in the tropics [Araguás-Araguás et al., 1998].

[27] Recent studies have suggested that the "amount effect" should better be interpreted to reflect the total amount of rainout that occurs upstream and particularly over the moisture source region [Joswiak et al., 2010; Kurita et al., 2009; Pausata et al., 2011; Vuille et al., 2005; Yuan et al., 2004]. Consistent with this interpretation, our cellulose $\delta^{18} \mathrm{O}$ demonstrates high degree of correlations with precipitation and OLR over the IPWP, which is the moisture source region for our site. We therefore argue that our cellulose record documents convective intensity over the IPWP. On an interannual basis, convection over the IPWP is modulated by the ENSO. Our cellulose record compares well with ENSO indices as well as coral $\delta^{18} \mathrm{O}$ records from the tropical Pacific Ocean that have been used to reconstruct ENSO.

[28] Our study suggests tree cellulose $\delta^{18} \mathrm{O}$ from tropical coastal regions is a robust, high resolution terrestrial proxy for hydrological conditions over tropical oceans. The connection that links water isotope behaviors to atmospheric circulations makes it possible to infer how ENSO is manifested in its peripheral regions. As a terrestrial proxy, it complements the marine proxy of coral, and it also possesses the advantage of precise chronology. However, the growth patterns of trees must be better constrained in order to extend this application to monthly or seasonal resolution using subring measurements. In addition, over most of the low elevation tropics, trees do not exhibit prominent growth bands that reflect annual growth behavior. Still, promising work has been done using tropical trees without visible ring structures [Anchukaitis and Evans, 2010]. We therefore believe that our study will motivate additional work on trees in reconstructing tropical climate variability.

[29] Acknowledgments. This work is supported by National Science Foundation Awards AGS-0902507 and ATM-0402474. The authors would like to thank Miguel Rincon for analytical assistance, and Julien Emile-Geay for help on statistical methods.

\section{References}

Aggarwal, P. K., K. Frohlich, K. M. Kulkarni, and L. L. Gourcy (2004), Stable isotope evidence for moisture sources in the Asian summer monsoon under present and past climate regimes, Geophys. Res. Lett., 31, L08203, doi:10.1029/2004GL019911.

Anchukaitis, K. J., and M. N. Evans (2010), Tropical cloud forest climate variability and the demise of the Monteverde golden toad, Proc. Natl. Acad. Sci. U. S. A., 107(11), 5036-5040, doi:10.1073/pnas.0908572107.

Araguás-Araguás, L., K. Froehlich, and K. Rozanski (1998), Stable isotope composition of precipitation over Southeast Asia, J. Geophys. Res., 103 (D22), 28,721-28,742, doi:10.1029/98JD02582.

Asami, R., T. Yamada, Y. Iryu, T. M. Quinn, C. P. Meyer, and G. Paulay (2005), Interannual and decadal variability of the western Pacific sea surface condition for the years 1787-2000: Reconstruction based on stable isotope record from a Guam coral, J. Geophys. Res., 110, C05018, doi:10.1029/2004JC002555.

Ashok, K., S. K. Behera, S. A. Rao, H. Y. Weng, and T. Yamagata (2007), El Niño Modoki and its possible teleconnection, J. Geophys. Res., 112, C11007, doi:10.1029/2006JC003798.

Buckley, B. M., K. Duangsathaporn, K. Palakit, S. Butler, V. Syhapanya, and N. Xaybouangeun (2007), Analyses of growth rings of Pinus merkusii from Lao PDR, For. Ecol. Manage., 253(1-3), 120-127, doi:10.1016/ j.foreco.2007.07.018.

Buckley, B. M., K. J. Anchukaitis, D. Penny, R. Fletcher, E. R. Cook, M. Sano, C. N. Le, A. Wichienkeeo, T. M. Ton, and M. H. Truong (2010), Climate as a contributing factor in the demise of Angkor, Cambodia, Proc. Natl. Acad. Sci. U. S. A., 107(15), 6748-6752, doi:10.1073/pnas.0910827107.

Charles, C. D., D. E. Hunter, and R. G. Fairbanks (1997), Interaction between the ENSO and the Asian monsoon in a coral record of tropical climate, Science, 277(5328), 925-928, doi:10.1126/science.277.5328.925.

Charles, C. D., K. Cobb, M. D. Moore, and R. G. Fairbanks (2003), Monsoon-tropical ocean interaction in a network of coral records spanning the 20th century, Mar. Geol., 201(1-3), 207-222, doi:10.1016/S00253227(03)00217-2.

Chen, J. Y., B. E. Carlson, and A. D. Del Genio (2002), Evidence for strengthening of the tropical general circulation in the 1990s, Science, 295(5556), 838-841, doi:10.1126/science.1065835.

Clement, A. C., M. A. Cane, and R. Seager (2001), An orbitally driven tropical source for abrupt climate change, J. Clim., 14(11), 2369-2375, doi:10.1175/1520-0442(2001)014<2369:AODTSF>2.0.CO;2.

Cobb, K. M., C. D. Charles, H. Cheng, and R. L. Edwards (2003), El Niño/ Southern Oscillation and tropical Pacific climate during the last millennium, Nature, 424(6946), 271-276, doi:10.1038/nature01779. 
Cole, J. E., R. G. Fairbanks, and G. T. Shen (1993), Recent variability in the Southern Oscillation-Isotopic results from a Tarawa Atoll coral, Science, 260(5115), 1790-1793, doi:10.1126/science.260.5115.1790.

Cole, J. E., R. B. Dunbar, T. R. McClanahan, and N. A. Muthiga (2000), Tropical Pacific forcing of decadal SST variability in the western Indian Ocean over the past two centuries, Science, 287(5453), 617-619, doi:10.1126/science.287.5453.617.

D’Arrigo, R., M. Barbetti, M. Watanasak, B. Buckley, P. Krusic, S. Boonchirdchoo, and S. Sarutanon (1997), Progress in dendroclimatic studies of mountain pine in northern Thailand, IAWA J., 18(4), 433-444.

Deser, C., A. S. Phillips, and J. W. Hurrell (2004), Pacific interdecadal climate variability: Linkages between the tropics and the North Pacific during boreal winter since 1900, J. Clim., 17(16), 3109-3124, doi:10.1175/ 1520-0442(2004)017<3109:PICVLB>2.0.CO;2.

Evans, M. N., and D. P. Schrag (2004), A stable isotope-based approach to tropical dendroclimatology, Geochim. Cosmochim. Acta, 68(16), 3295-3305, doi:10.1016/j.gca.2004.01.006.

Evans, M. N., R. G. Fairbanks, and J. L. Rubenstone (1999), The thermal oceanographic signal of El Niño reconstructed from a Kiritimati Island coral, J. Geophys. Res., 104(C6), 13,409-13,421, doi:10.1029/1999JC900001.

Gaudinski, J. B., T. E. Dawson, S. Quideau, E. A. G. Schuur, J. S. Roden, S. E. Trumbore, D. R. Sandquist, S. W. Oh, and R. E. Wasylishen (2005), Comparative analysis of cellulose preparation techniques for use with ${ }^{13} \mathrm{C}$, ${ }^{14} \mathrm{C}$, and ${ }^{18} \mathrm{O}$ isotopic measurements, Anal. Chem., 77(22), 7212-7224, doi:10.1021/ac050548u.

Gergis, J. L., and A. M. Fowler (2009), A history of ENSO events since AD 1525: Implications for future climate change, Clim. Change, 92(3-4), 343-387, doi:10.1007/s10584-008-9476-z.

Graham, N. E. (1995), Simulation of recent global temperature trends, Science, 267(5198), 666-671, doi:10.1126/science.267.5198.666.

Johnson, N. C., and S. P. Xie (2010), Changes in the sea surface temperature threshold for tropical convection, Nat. Geosci., 3(12), 842-845, doi:10.1038/ngeo1008.

Joswiak, D. R., T. Yao, G. Wu, B. Xu, and W. Zheng (2010), A 70-yr record of oxygen-18 variability in an ice core from the Tanggula Mountains, central Tibetan Plateau, Clim. Past, 6(2), 219-227, doi:10.5194/ cp-6-219-2010.

Kao, H. Y., and J. Y. Yu (2009), Contrasting Eastern-Pacific and CentralPacific types of ENSO, J. Clim., 22(3), 615-632, doi:10.1175/ 2008JCLI2309.1.

Kaplan, A., M. A. Cane, Y. Kushnir, A. C. Clement, M. B. Blumenthal, and B. Rajagopalan (1998), Analyses of global sea surface temperature 1856-1991, J. Geophys. Res., 103(C9), 18,567-18,589, doi:10.1029/ 97JC01736.

Kurita, N., K. Ichiyanagi, J. Matsumoto, M. D. Yamanaka, and T. Ohata (2009), The relationship between the isotopic content of precipitation and the precipitation amount in tropical regions, J. Geochem. Explor., 102(3), 113-122, doi:10.1016/j.gexplo.2009.03.002.

Latif, M., and T. P. Barnett (1994), Causes of decadal climate variability over the North Pacific and North America, Science, 266(5185), 634-637, doi:10.1126/science.266.5185.634.

Leavitt, S. W., K. Treydte, and Y. Liu (2010), Environment in time and space: Opportunities from tree-ring isotope networks, in Isoscapes: Understanding Movement, Pattern, and Process on Earth Through Isotope Mapping, edited by J. B. West et al., pp. 113-135, Springer, Dordrecht, Netherlands.

Linsley, B. K., and R. Thunell (1990), The record of deglaciation in the Sulu Sea: Evidence for the Younger Dryas event in the tropical western Pacific, Paleoceanography, 5(6), 1025-1039, doi:10.1029/PA005i006p01025.

Mantua, N. J., and S. R. Hare (2002), The Pacific Decadal Oscillation, J. Oceanogr., 58(1), 35-44, doi:10.1023/A:1015820616384.

McPhaden, M. J., and J. Picaut (1990), El Niño-Southern Oscillation displacements of the western equatorial Pacific warm pool, Science, 250(4986), 1385-1388, doi:10.1126/science.250.4986.1385.

Mitas, C. M., and A. Clement (2005), Has the Hadley cell been strengthening in recent decades?, Geophys. Res. Lett., 32, L03809, doi:10.1029/ 2004 GL021765.

Newman, M., P. D. Sardeshmukh, and J. W. Bergman (2000), An assessment of the NCEP, NASA, and ECMWF reanalyses over the tropical west Pacific warm pool, Bull. Am. Meteorol. Soc., 81(1), 41-48, doi:10.1175/1520-0477(2000)081<0041:AAOTNN>2.3.CO;2.

Newton, A., R. Thunell, and L. Stott (2006), Climate and hydrographic variability in the Indo-Pacific Warm Pool during the last millennium, Geophys. Res. Lett., 33, L19710, doi:10.1029/2006GL027234.

Oppo, D. W., Y. Rosenthal, and B. K. Linsley (2009), 2,000-year-long temperature and hydrology reconstructions from the Indo-Pacific warm pool, Nature, 460(7259), 1113-1116, doi:10.1038/nature08233.
Partin, J. W., K. M. Cobb, J. F. Adkins, B. Clark, and D. P. Fernandez (2007), Millennial-scale trends in west Pacific warm pool hydrology since the Last Glacial Maximum, Nature, 449(7161), 452-455, doi:10.1038/nature06164.

Pausata, F. S. R., D. S. Battisti, K. H. Nisancioglu, and C. M. Bitz (2011), Chinese stalagmite $\delta^{18} \mathrm{O}$ controlled by changes in the Indian monsoon during a simulated Heinrich event, Nat. Geosci., 4(7), 474-480, doi:10.1038/ngeo1169.

Pumijumnong, N., and D. Eckstein (2011), Reconstruction of pre-monsoon weather conditions in northwestern Thailand from the tree-ring widths of Pinus merkusii and Pinus kesiya, Trees Struct. Funct., 25(1), 125-132, doi:10.1007/s00468-010-0528-4.

Pumijumnong, N., and T. Wanyaphet (2006), Seasonal cambial activity and tree-ring formation of Pinus merkusii and Pinus kesiya in Northern Thailand in dependence on climate, For. Ecol. Manage., 226(1-3), 279-289, doi:10.1016/j.foreco.2006.01.040.

Quinn, T. M., T. J. Crowley, and F. W. Taylor (1996), New stable isotope results from a 173-year coral from Espiritu Santo, Vanuatu, Geophys. Res. Lett., 23(23), 3413-3416, doi:10.1029/96GL03169.

Quinn, T. M., T. J. Crowley, F. W. Taylor, C. Henin, P. Joannot, and Y. Join (1998), A multicentury stable isotope record from a New Caledonia coral: Interannual and decadal sea surface temperature variability in the southwest Pacific since 1657 AD, Paleoceanography, 13(4), 412-426, doi:10.1029/98PA00401

Quinn, T. M., F. W. Taylor, and T. J. Crowley (2006), Coral-based climate variability in the Western Pacific Warm Pool since 1867, J. Geophys. Res., 111, C11006, doi:10.1029/2005JC003243.

Roden, J. S., G. G. Lin, and J. R. Ehleringer (2000), A mechanistic model for interpretation of hydrogen and oxygen isotope ratios in tree-ring cellulose, Geochim. Cosmochim. Acta, 64(1), 21-35, doi:10.1016/S0016-7037(99) 00195-7.

Sternberg, L. D. L. O. (2009), Oxygen stable isotope ratios of tree-ring cellulose: The next phase of understanding, New Phytol., 181(3), 553-562, doi:10.1111/j.1469-8137.2008.02661.x.

Stott, L., C. Paulsen, S. Lund, and R. Thunell (2002), Super ENSO and global climate oscillations at millennial time scales, Science, 297, 222-226.

Tanaka, H. L., N. Ishizaki, and D. Nohara (2005), Intercomparison of the intensities and trends of Hadley, Walker and Monsoon circulations in the global warming projections, SOLA, 1, 77-80.

Timmermann, A., J. Oberhuber, A. Bacher, M. Esch, M. Latif, and E. Roeckner (1999), Increased El Niño frequency in a climate model forced by future greenhouse warming, Nature, 398(6729), 694-697, doi:10.1038/19505.

Tudhope, A. W., G. B. Shimmield, C. P. Chilcott, M. Jebb, A. E. Fallick, and A. N. Dalgleish (1995), Recent changes in climate in the far western equatorial Pacific and their relationship to the Southern Oscillation: Oxygen isotope records from massive corals, Papua New Guinea, Earth Planet. Sci. Lett., 136(3-4), 575-590, doi:10.1016/0012-821X(95)00156-7.

Tudhope, A. W., C. P. Chilcott, M. T. McCulloch, E. R. Cook, J. Chappell, R. M. Ellam, D. W. Lea, J. M. Lough, and G. B. Shimmield (2001), Variability in the El Niño-Southern Oscillation through a glacial-interglacial cycle, Science, 291(5508), 1511-1517, doi:10.1126/science.1057969.

Urban, F. E., J. E. Cole, and J. T. Overpeck (2000), Influence of mean climate change on climate variability from a 155-year tropical Pacific coral record, Nature, 407(6807), 989-993, doi:10.1038/35039597.

Visser, K., R. Thunell, and L. Stott (2003), Magnitude and timing of temperature change in the Indo-Pacific warm pool during deglaciation, Nature, 421(6919), 152-155, doi:10.1038/nature01297.

Vuille, M., M. Werner, R. S. Bradley, and F. Keimig (2005), Stable isotopes in precipitation in the Asian monsoon region, J. Geophys. Res., 110, D23108, doi:10.1029/2005JD006022.

Wielicki, B. A., et al. (2002), Evidence for large decadal variability in the tropical mean radiative energy budget, Science, 295(5556), 841-844, doi:10.1126/science.1065837

Wigley, T. M. L., K. R. Briffa, and P. D. Jones (1984), On the average value of correlated time-series, with applications in dendroclimatology and hydrometeorology, J. Clim. Appl. Meteorol., 23(2), 201-213, doi:10.1175/15200450(1984)023<0201:OTAVOC >2.0.CO;2.

Yoshimura, K., M. Kanamitsu, D. Noone, and T. Oki (2008), Historical isotope simulation using Reanalysis atmospheric data, J. Geophys. Res., 113, D19108, doi:10.1029/2008JD010074.

Yuan, D. X., et al. (2004), Timing, duration, and transitions of the Last Interglacial Asian Monsoon, Science, 304(5670), 575-578, doi:10.1126/ science. 1091220 